\title{
Translating Multicultural Texts: Challenges and Solutions
}

\author{
Evgeniia V. Zimina, PhD
}

(D)/0000-0002-9619-9215

Department of Romance and Germanic Languages, Kostroma State University, Russia DOI: $h t t p s: / / d x . d o i . o r g / 10.46679 / 978819484830102$

\section{Abstract}

Translating literary texts involves decoding not only the language but also the cultural elements integrated into the text. The situation becomes even more challenging if the translated text is multicultural. The original text may be full of references, allusions and subtexts that can present certain difficulties even for native speakers. The translator faces the double challenge: not only to convey the plot, which is the least difficult part but make the reader feel the subtleties and nuances of the cultures presented in the text.

Cultures are not necessarily associated with different ethnic and religious identities. They may also refer to cultures of certain periods in history, cultures of age groups, cultures of local communities. Oversimplifications made by the translator rob the reader of the pleasure of reading and may create a distorted image of the writer and the text.

We aim to analyse typical translation errors made by translators of contemporary Russian fiction into English. The analysis is based on Narine Abgaryan's Three Apples Fell from the Sky and Dmitry Novikov's A Flame Out in the Sea, both originally written in Russian and characterised by a high degree of multiculturalism. We also suggest practical ways to overcome the difficulties arising in the process of translating multicultural texts. 


\section{This is a limited preview of the chapter.}

To read the full-text chapter, get access by purchasing this chapter or consider buying the complete book. If your library has subscription to EBSCOhost, the chapter including other chapters of the book can be accessed through your library.

This chapter is a part of the book, 'Contemporary Translation Studies' ISBN (paperback): 978-81-948483-0-1; ISBN (ebook): 978-81-948483-8-7

Book DOI: https://dx.doi.org/10.46679/9788194848301 
of certain passages will become neutral, and the cultural aspect of these passages will be lost.

Translations aim not only to render the plot of the translated text. It is a more complex process in which any detail, no matter how insignificant it seems, may play a crucial role.

\section{References}

Abgarayn N., Hayden Lisa C. (2020) Three Apples Fell from the Sky.

London: Oneworld Publications. Kindle edition.

Abgaryan N. (2016). Three Apples Fell from the Sky. Moscow: AST. (In Russ.) Alekseeva I.S. (2003). Professional Training of a Translator. St. Petersburg:

Soyuz. 20-21. (In Russ.)

Armitstead C., Wroe N., Cain S., Forrester W., Cuttle J., Willsher K.

(2020). "My family are too frightened to read my book": meet

Europe's most exciting authors. Retrieved from:

https://www.theguardian.com/books/2020/mar/07/shock-of-

new-novelists-stories-europe

Arutyunyan N.L. (2015). Multicultural literary discourse of Salman

Rushdie. Cognition, communication, discourse. (Philology). Kharkiv:

National Karazin University. 8-18. (In Russ).

Aslanyan Anna. (2011) Why Russian literature speaks English little.

Retrieved from:

https://www.bbc.com/russian/society/2011/04/110418_russian

_lit_english_translations (In Russ.)

Bachmann-Medick, Doris. (1996). Cultural Misunderstanding in

Translation: Multicultural Coexistence and Multicultural

Conceptions of the World. EESE 7. Retrieved from:

http://webdoc.gwdg.de/edoc/ia/eese/artic96/Bachmann/7_96.

html

Korinec Yu. (1973). There, over the river. The white night by the fire. Two 
novels about my uncle. Moscow: Detskaya literature. (In Russ). Lonergan Patrick. (2009) Preface. In: The Lieutenant of Inishmore (Student Edition) by Martin McDonagh. London: Bloomsbury. Kindle edition.

Massot Josefina (2020). Intimate Work: Lisa C. Hayden on translating Narine Abgaryan Retrieved from:

https://www.asymptotejournal.com/blog/2020/04/23/intimate -work-lisa-c-hayden-on-translating-narine-abgaryan/

Novikov D. (2017). A Flame Out in the Sea. Moscow: AST: Redakciya Eleny Shubinoj. (In Russ)

Novikov D., Culver Christopher. (2019). A Flame Out in the Sea. London: Glagoslav.

Pound, E. (1931). How to Read. New York: Haskell House.

Precup-Stigelbauer Laura-Rebecca, Tirban Narcisa, BanciuViorica.

(2012). Translation as a Means of Communication in a

Multicultural World. International Proceedings of Economic

Development and Research. 39, 166-170.

Smirnov L. (2015). Americans do not read Russian Literature. Retrieved from:

https://www.rosbalt.ru/moscow/2015/03/27/1382546.html (In Russ).

Tyurina S. Yu. (2004). Discourse as an object of the linguistic research.

Retrieved from: http://www.my-uni.ru/journal/clauses/129/(In Russ).

Voropaev A.N. (2019). Russian book publishing in 2018: meeting new minimum values. Retrieved from: http://www.unkniga.ru/bookrinok/knigniy-rinok/9348rossiyskoe-knigoizdanie-v-2018-navstrechu-novymminimumam.html(In Russ). 